\title{
Neurotrophic Ulcer Complicated By Stromal Melting
}

\author{
D. Jaafari ${ }^{1 *}$, N. Inzale ${ }^{1}$, S. Boutgayout ${ }^{1}$, H. Atidi ${ }^{1}$, S. Belghmaidi ${ }^{1}$, I. Hajji ${ }^{1}$, A. Moutaouakil ${ }^{1}$
}

${ }^{1}$ Ophtalmology Department, CHU Mohamed VI Marrakech, Morocco

DOI: $\underline{10.36347 / \text { simcr.2021.v09i04.037 }}$

| Received: 18.03.2021 | Accepted: 25.04.2021 | Published: 29.04.2021

*Corresponding author: D. Jaafari

Abstract

Case Report

Neurotrophic keratitis results from partial or complete denervation of the cornea from various origins, including viral. We report the case of a monophthalmic patient, followed for dry eyes. She was pseudophakic patient who presented, after a cataract surgery, a neurotrophic ulcer complicated by stromal melting.

Keywords: Neurotrophic keratitis, cornea, monophthalmic patient, dry eyes.

Copyright $\odot 2021$ The Author(s): This is an open-access article distributed under the terms of the Creative Commons Attribution 4.0 International License (CC BY-NC 4.0) which permits unrestricted use, distribution, and reproduction in any medium for non-commercial use provided the original author and source are credited.

\section{INTRODUCTION}

Neurotrophic keratitis results from partial or complete denervation of the cornea from various origins, including viral. They cause disorders of corneal sensitivity and chronic degenerative damage to the corneal epithelium. They can be complicated by chronic ulcers, epithelial and then stromal that can perforate after. Neurotrophic ulcers that are resistant to topical treatments usually require blepharrorrhaphy, tarsorraphy, or conjunctival overlay, which is engaging the visual prognosis.

We report the case of a monophthalmic patient, followed for dry eyes. She was pseudophakic patient who presented, after a cataract surgery, a neurotrophic ulcer complicated by stromal melting.

\section{Clinical Case Report}

Mrs. F., 68 years old, monophthalmic of her left eye (old trauma of her right eye).She was followed for a dry syndrome with a negative etiological report, and operated for cataract of the left eye (manual extracapsular extraction), whose postoperative results were marked by the occurrence of a neurotrophic ulcer put under artificial tears with a good improvement.

Missed for 6 months, the patient presented to the emergency department for a painful red eye with a decrease in visual acuity.

The patient had a visual acuity in her left eye at "count the fingers closely", conjunctival hyperemia, a stromal melting with a $360^{\circ}$ neovascularization, a collapsed anterior chamber and an externalized PMMA implant in both sides, nasal and temporal (Figure-1).

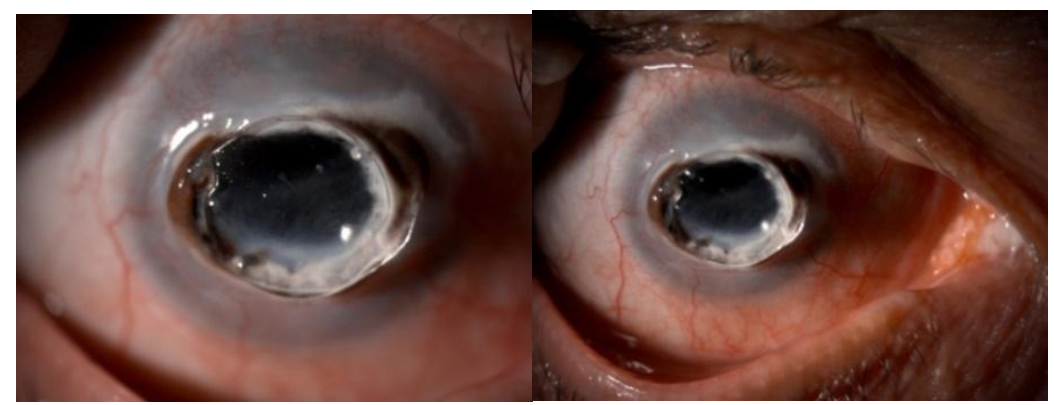

Fig-1: Biomicroscopic photography: stromal melting and externalized PMMA implant

The patient had benefited from a multi-layer amniotic membrane graft and a tarsorraphy with the prospect of an emergency transfixion keratoplasty.
Missed for one month, the patient presented to the emergency department for a burst of the left eye with a visual acuity at no perception of light (Figure-2). 
Then the patient was programmed for evisceration of the left eye.

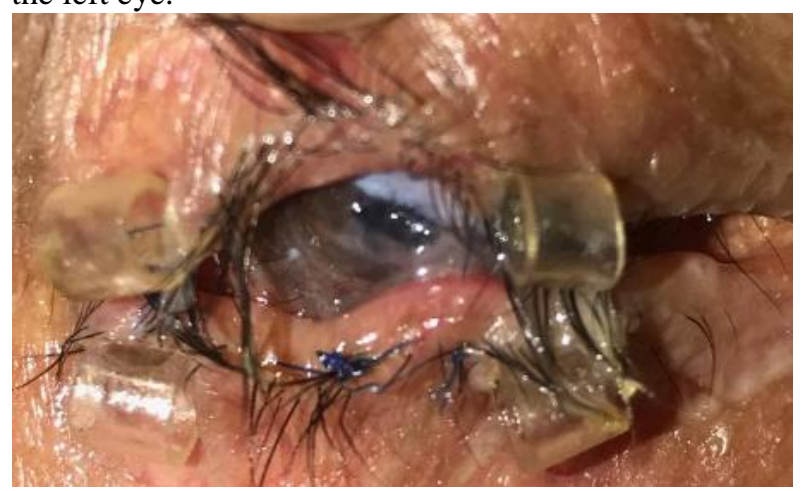

Fig-2: Bursting of the left eye with externalization of the implant and exit of the vitreous

\section{DISCUSSION}

The neurotrophic ulcer evolves in different stages of severity. It may manifest as a decrease in visual acuity, conjunctival hyperemia, tearing, and pain that may be absent or moderate. The clinical signs begin with instability of the tear film and irregularity of the epithelial surface, followed by superficial punctate keratitis. Then the epithelial ulcer appears, characterized by its oval form. It is sometimes complicated by a stromal edema and then the stromal ulcer occurs [1].

Among the causes of corneal neurotrophic ulcer is corneal hypoesthesia, the most common cause of it, is the aftereffect of herpetic or zosterian infections. This hypoesthesia leads to a disorder of the ocular surface then an alteration of the tear film because of a decrease of the lacrimal secretion, an increase in its viscosity and a decrease in the blink reflex. The corneal epithelial cells lose their microvilli causing lack of adhesion of the tear film leading to corneal epithelial suffering [2].

The usual treatment of trophic ulcers is often difficult. The first is the removal of all eye drops that are toxic to the ocular surface, including eye drops with preservatives [3]. The treatment will be based on lubricants without preservatives, to which can be added antiseptic eye drops without preservatives too. If there is no improvement, the placement of a therapeutic lens may be proposed. Autologous serum eye drop, rich in growth factors and protease inhibitors, may also be used $[4,5]$.

In the stage of stromal ulcer, the preservation of the integrity of the eyeball prevails on the rehabilitation of the visual function. Amniotic membrane graft is used in refractory ulcers or preperforative or perforated ulcers [6]. It is used most often sutured in the bottom of the ulcer in one or more layers. It has anti-inflammatory, healing properties and also provides a physical support that facilitates the migration of cells from ulcer banks. In case of failure of the amniotic membrane graft, a partial or total conjunctival coverage may sometimes be necessary to anatomically preserve the eyeball [7]. In very small perforations, cyanoacrylate or biological glues of the fibrin glue type are sometimes used [8]. A temporary tarsorraphy or Botulin toxin injections can be used to manage the problem, especially in case of associated eyelid malocclusion. And as a last resort, emergency lamellar or transfixing corneal grafting called "plug» that can be used in large diameter perforations [9].

\section{CONCLUSION}

The management of neurotrophic corneal ulcer is difficult. The clinical approach must include accurate interrogation and systematic clinical examination; during it the evaluation of the size and the depth as well as the sensitivity is important. Therapeutic management must be rapid, adapted and sequential, because the visual function, more of that, the integrity of the globe are most often threatened, as well as the general prognosis.

\section{REFERENCES}

1. Chang BH, Groos EB. Neurotrophic keratitis. In: Krachmer JH, Mannis MJ, Holland EJ. Eds. Cornea. 3rd ed. Mosby: St Louis: Mosby; 2011.

2. Cavanagh HD, Colley AM. The molecular basis of neurotrophic keratitis. Acta Ophthalmol Suppl. 1989; 192: 115-34.

3. Gueudry J, Lebel H, Muraine M. Severe corneal complications associated with topical indomethacin use. Br J Ophthalmol. 2010;94(1):133-4.

4. Sacchetti M, Lambiase A. Diagnosis and management of neurotrophic keratitis. Clin Ophthalmol. 2014; 8:571-79.

5. Matsumoto Y, Dogru M, Goto E, Ohashi Y, Kojima T, Ishida R, Tsubota K. Autologous serum application in the treatment of neurotrophic keratopathy. Ophthalmology. 2004 Jun 1;111(6):1115-20.

6. Muraine M, Gueudry J, Toubeau D, Gardea E, Verspyck E, Menguy E, Brasseur G. Advantages of amniotic membrane transplantation in eye surface diseases. Journal francais d'ophtalmologie. 2006 Nov 1;29(9):1070-83.

7. Boidin H, Gueudry J, Portmann A, Muraine M. Conjunctival flap: still a relevant procedure. J Fr Ophtalmol. 2012;35(3):170-5.

8. Vera L, Benzerroug M, Gueudry J, Varin R, Haghighat S, Gérard G, Muraine M. An update on the use of tissue adhesives in ophthalmology. Journal francais d'ophtalmologie. 2009 Mar 19;32(4):290-305.

9. Muraine, M. Greffes de cornée «à chaud» ou kératoplasties Ophtalmologie. 2004, 1(4), 201-216. 